\title{
GZMB wt Allele
}

National Cancer Institute

\section{Source}

National Cancer Institute. GZMB wt Allele. NCI Thesaurus. Code C104354.

Human GZMB wild-type allele is located in the vicinity of $14 q 11.2$ and is approximately 3 $\mathrm{kb}$ in length. This allele, which encodes granzyme B protein, is involved in both proteolysis and cellular immune responses. 